\title{
Use of a multilayer snow model to assess grazing conditions for reindeer
}

\author{
D. VIKHAMAR-SCHULER, ${ }^{1}$ I. HANSSEN-BAUER, ${ }^{1,2}$ T.V. SCHULER, ${ }^{3}$ \\ S.D. MATHIESEN, ${ }^{4,5}$ M. LEHNING ${ }^{6,7}$ \\ ${ }^{1}$ Norwegian Meteorological Institute, Oslo, Norway \\ E-mail: dagrun@met.no \\ ${ }^{2}$ Telemark University College, Bø, Norway \\ ${ }^{3}$ Department of Geosciences, University of Oslo, Oslo, Norway \\ ${ }^{4}$ UArctic EALAT Institute at International Centre for Reindeer Husbandry, Kautokeino, Norway \\ ${ }^{5}$ Norwegian School of Veterinary Science, Troms $\varnothing$, Norway \\ ${ }^{6}$ WSL, Swiss Federal Institute for Forest, Snow and Landscape Research, SLF, Davos, Switzerland \\ ${ }^{7}$ CRYOS, School of Architecture, Civil and Environmental Engineering (ENAC), École Polytechnique Fédérale de Lausanne \\ (EPFL), Lausanne, Switzerland
}

\begin{abstract}
High-density snow layers deteriorate grazing conditions for reindeer during winter. We compare two different methods for identifying past winters with difficult grazing conditions for reindeer in Kautokeino, northern Norway. A long-term climate analysis based on monthly values of precipitation and temperature (1900-2011) demonstrated that the reported winters were difficult to identify systematically. The processes leading to hard layers or ground-ice layers occur on daily, not monthly, timescales, and whether or not specific conditions are problematic depends on the development throughout the winter, not just on single values. To better analyse the weather conditions and development over time that favour the formation of high-density snow layers, we apply the multilayer model SNOWPACK over the period 1956-2010. We simulate the evolution of the snowpack by forcing the model with 6 hour interval meteorological data. The model output was analysed by summing up the vertical extent of the simulated high-density snow layers $\left(>350 \mathrm{~kg} \mathrm{~m}^{-3}\right)$ for each winter. These results were compared with historical records of difficult winter grazing conditions reported in the period 19562010. In particular, the heavy losses of reindeer during the catastrophic 1967/68 winter were caused by the occurrence of ground ice together with long snow-cover duration. This unfavourable coincidence is well reproduced by our model results, together with eight of the ten reported difficult winters.
\end{abstract}

\section{INTRODUCTION}

\subsection{Background}

In the past, extraordinary snow conditions have been reported to have negative and sometimes even catastrophic consequences for reindeer herding in Arctic regions (Reimers, 1982; Forchhammer and Boertmann, 1993; Heggberget and others, 2002; Kohler and Aanes, 2004; Päiviö, 2006; Hansen and others, 2011). Ground-ice or high-density layers inhibit reindeer from penetrating the snowpack and grazing the underlying vegetation. A large spatial extent of these layers, combined with other ecological factors (e.g. cold summer or nutritionally poor forage quality), may reduce the number of reindeer. However, this is only an empirically founded hypothesis, and quantitative measurements and analysis are required (Tyler, 2010; Hansen and others, 2011). Recently, it has also been demonstrated that icing events at Svalbard influence reindeer movement (Stien and others, 2010).

Snowpack stratigraphy and penetrability are determined by winter weather conditions. As climate change affects the atmospheric circulation pattern, it may also affect the frequency of weather situations leading to difficult grazing conditions. It is therefore important to understand the physical processes leading to formation of high-density snow layers and ground-ice layers and linking them to weather and climate patterns. In this context, it is important to recognize that the mechanical properties of the snow cover are more decisive for penetrability than is snow depth alone. High-density layers within the snow cover or ice conditions at the snow/ground interface are caused by specific weather conditions (e.g. warm spells or rain-onsnow (ROS) events followed by cold periods). The effect of ROS events on the thermal regime at the snow/ground interface has been investigated by, for example, Putkonen and Roe (2003) and Westermann and others (2011). To understand how future climate may affect reindeer husbandry, it is important to recognize how past weather events have influenced mechanical snow properties and thereby the availability of reindeer pastures. Observations from Abisko, northern Sweden, document changes in snow properties over a 50 year period (1961-2009), particularly a significant increase in very hard snow layers at ground level (Johansson and others, 2011). The observed changes were assumed to result from increasing temperatures at the start and end of the snow season. Bulygina and others (2010) report similar changes in ground-ice layers in northern Eurasia from 1966 to 2007. Likewise, future climate change will probably also influence the frequency of warm spells and ROS events (Putkonen and Roe, 2003), and thereby the physical properties of the snowpack.

Different statistical approaches have been attempted to analyse winter climate, ground-ice layers and reindeer population dynamics. Different parameters have been 
correlated with annual population size (e.g. winter precipitation, snow depth, temperature indices) (Aanes and others, 2000; Kumpula and Colpaert, 2003; Tveraa and others, 2007). Aanes and others (2000) showed that the amount of winter precipitation is highly correlated with the population dynamics of wild reindeer at Svalbard. Kohler and Aanes (2004) carried out a more sophisticated analysis of the same reindeer population, by modelling ground-ice thickness using a simple degree-day model. Winter precipitation was divided into two components, snow and ground ice, using temperature thresholds. Their statistical analysis showed that ground-ice thickness explained a large part of the reindeer population dynamics over the years 1978-2002. However, their degree-day model is limited by simple assumptions of fixed thresholds for determining snow or rain, and snow density is excluded since water passes directly to the bottom to form ground ice. High-density layers forming within the snowpack are therefore not accounted for.

In order to analyse individual snow layers as part of the snow profile with respect to access to forage, the model of choice must be a detailed snow model, which treats mechanical properties of individual (thin) layers. There are two models that have a particular focus on the mechanical properties of individual snow layers, because they have been developed for avalanche warning applications: the French model Crocus (Brun and others, 1989, 1992, 2013; Vionnet and others, 2012) and the Swiss model SNOWPACK (Lehning and others, 1999; Lehning and Fierz, 2008). Both allow individual precipitation events to be simulated as characteristic layers with distinct mechanical properties.

We choose SNOWPACK, which has already been evaluated for the Finnish climate (Rasmus and others, 2007) and has been used for climate change scenario calculations in Finland (Rasmus and others, 2004). SNOWPACK simulates the snow layers using meteorological driving data of high time resolution. In this way, both low- and high-density snow layers are simulated. The model allows study of the weather conditions leading to formation of high-density snow layers. As well as weather and climate, both political and socio-economic factors relevant to reindeer management influence the reindeer population in a region, but we restrict our analysis to the climatic causes contributing to favourable or difficult winter grazing conditions. This study was conducted within the framework of the International Polar Year project EALAT, which addressed the impact of climate change on reindeer pastoralism (Eira and others, 2010, 2013; Magga and others, 2011; Maynard and others, 2011; Eira, 2012). We provide a new approach to reindeer ecology by applying a physically based snow model to identify the occurrence of high-density layers.

\subsection{Objectives}

The aim of our paper is to investigate and compare the performance of two different methods for identifying winters reported to have been difficult for the reindeer population in the past in Kautokeino, northern Norway. We first carry out a statistical analysis of climate data over a long period (19002011) and compare with the reported years. We analyse seasonal values for temperature and precipitation, aggregated for autumn (September-November), winter (December-February) and spring (March-May) and compare with the standard normal period 1961-90. Secondly, we investigate the feasibility of using the multilayer snow model SNOWPACK (Lehning and others, 1999; Bartelt and
Lehning, 2002; Lehning and others, 2002a,b) to identify high-density snow layers or ground-ice conditions during the years 1956-2010. The model is driven by synoptic data from a weather station located in Kautokeino, which we consider is representative of a larger area. We evaluate the model results using snow temperature measurements, snow profile observations and literature records of difficult winters for reindeer herding.

\section{THE SNOW MODEL SNOWPACK}

We apply the physical multilayer snow model SNOWPACK to simulate the evolution of the snow stratigraphy (Lehning and others, 1999, 2002a,b; Bartelt and Lehning, 2002). SNOWPACK is a predictive model that uses Lagrangian finite elements to solve for heat and mass transfer, stresses and strain within the snowpack. Snow is modelled as a three-phase porous medium consisting of ice, water and air. Since the model has been developed specifically for snow avalanche warning, its strength lies in the simulation of layers that are potentially important for triggering avalanches, such as surface hoar (Stössel and others, 2010) or crusts (Lehning and others, 2002b). This property makes the model particularly useful for the ecological application discussed here. With respect to avalanche warning, the model has been validated for alpine snow conditions (Etchevers and others, 2004; Schirmer and others, 2010), for the maritime snow of Japan (Yamaguchi and others, 2004; Nishimura and others, 2005; Hirashima and others, 2008) and for the continental snow cover in the Rocky Mountains (Lundy and others, 2001) and Canada (Bellaire and others, 2011). Additionally, it has also been validated for five boreal regions in Finland with various winter climate conditions (Rasmus and others, 2007). Rasmus and others (2007) found that the model performance improved with increasing latitude, which is probably related to increasingly cold weather conditions. They also observed a decrease in the variation of the snowpack structure with increasing latitude. Better performance was obtained during early winter than during the melting period. SNOWPACK has been used to predict possible future snow structures in Finland (Rasmus and others, 2004; Rasmus, 2005).

SNOWPACK simulates the development of the snowpack during winter, based on meteorological input data. Required input parameters are air temperature, relative humidity, precipitation (or snow depth), snow surface temperature, ground surface temperature, incoming longwave radiation (or cloud cover), shortwave radiation, wind speed and wind direction. For the specified time-step, the resulting outputs are stratigraphies of, for example, snow temperature, grain types, grain sizes, liquid water content and snow density.

\section{STUDY AREA}

The study area Kautokeino (Sami name: Guovdageaidnu) $\left(69^{\circ} \mathrm{N}, 23^{\circ} \mathrm{E}\right)$ is located in a continental setting in northern Norway at $\sim 300$ m a.s.l. at the Finnmark plateau (Fig. 1), one of the largest reindeer-herding regions in the world (Magga and others, 2011). There are about 180000 reindeer in Finnmark, and $\sim 2600$ people are active reindeer herders (Mathiesen and Magga, 2011).

Except for a few small high-alpine localities elsewhere, inland Finnmark is the coldest and driest area in Scandinavia on an annual basis, and especially during winter (Tveito and 


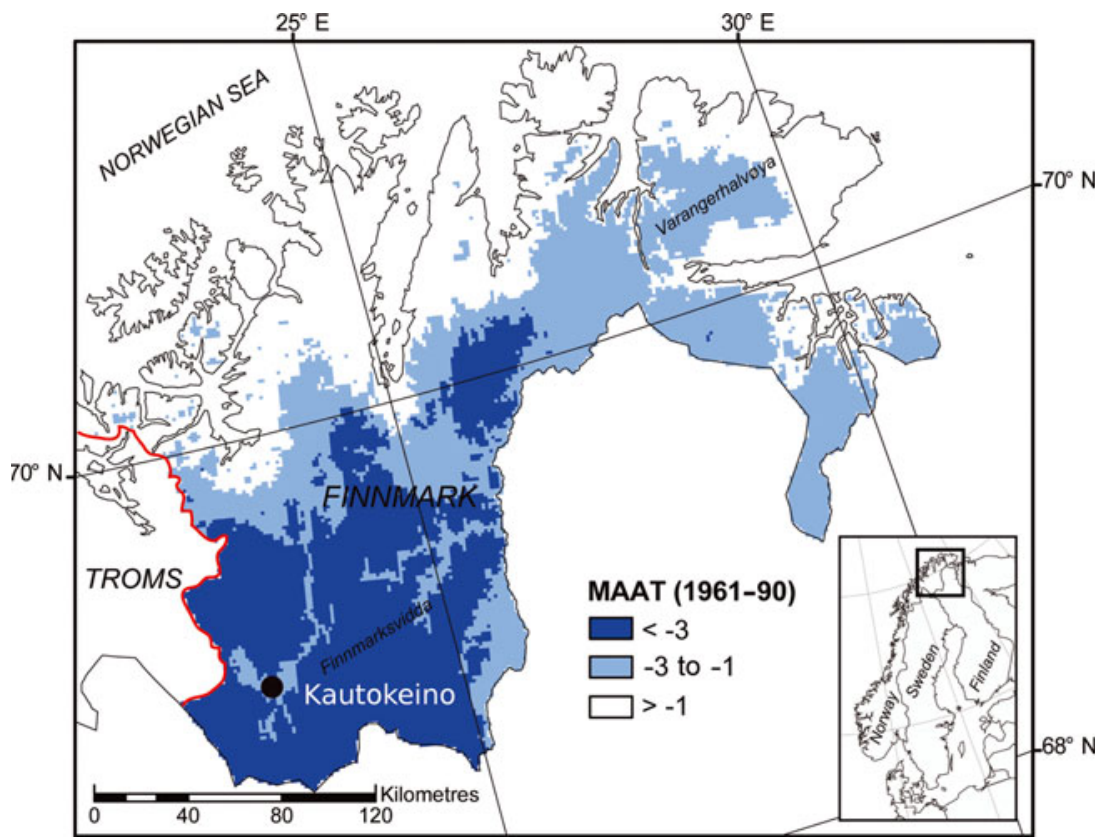

Fig. 1. The study area Kautokeino (black dot), located in western Finnmark, northern Norway. Three classes of mean annual air temperature (MAAT, 1961-90) indicate regions with increasing probabilities of permafrost (Isaksen and others, 2008): (1) no permafrost where MAAT $>-1{ }^{\circ} \mathrm{C}$; (2) discontinuous and sporadic permafrost where $-1{ }^{\circ} \mathrm{C} \geq$ MAAT $\geq-3^{\circ} \mathrm{C}$; and (3) permafrost widespread above timberline in areas where MAAT $<-3^{\circ} \mathrm{C}$. Kautokeino is located in a region with high probability of sporadic and discontinuous permafrost (class 2 ).

others, 1997, 2000). The snow cover is therefore relatively shallow, though the ground is covered by snow $\sim 7$ months per year (Vikhamar-Schuler and others, 2010a). Snow data from 1956 to 2011 (Fig. 2) show that the onset of the snow season varied by $\sim 2$ months, while the end varied by $\sim 1$ month during this period. The winter maximum snow depth varied from $<50 \mathrm{~cm}$ to almost $1 \mathrm{~m}$. Even though the Finnmark plateau is cold and dry by Scandinavian standards,
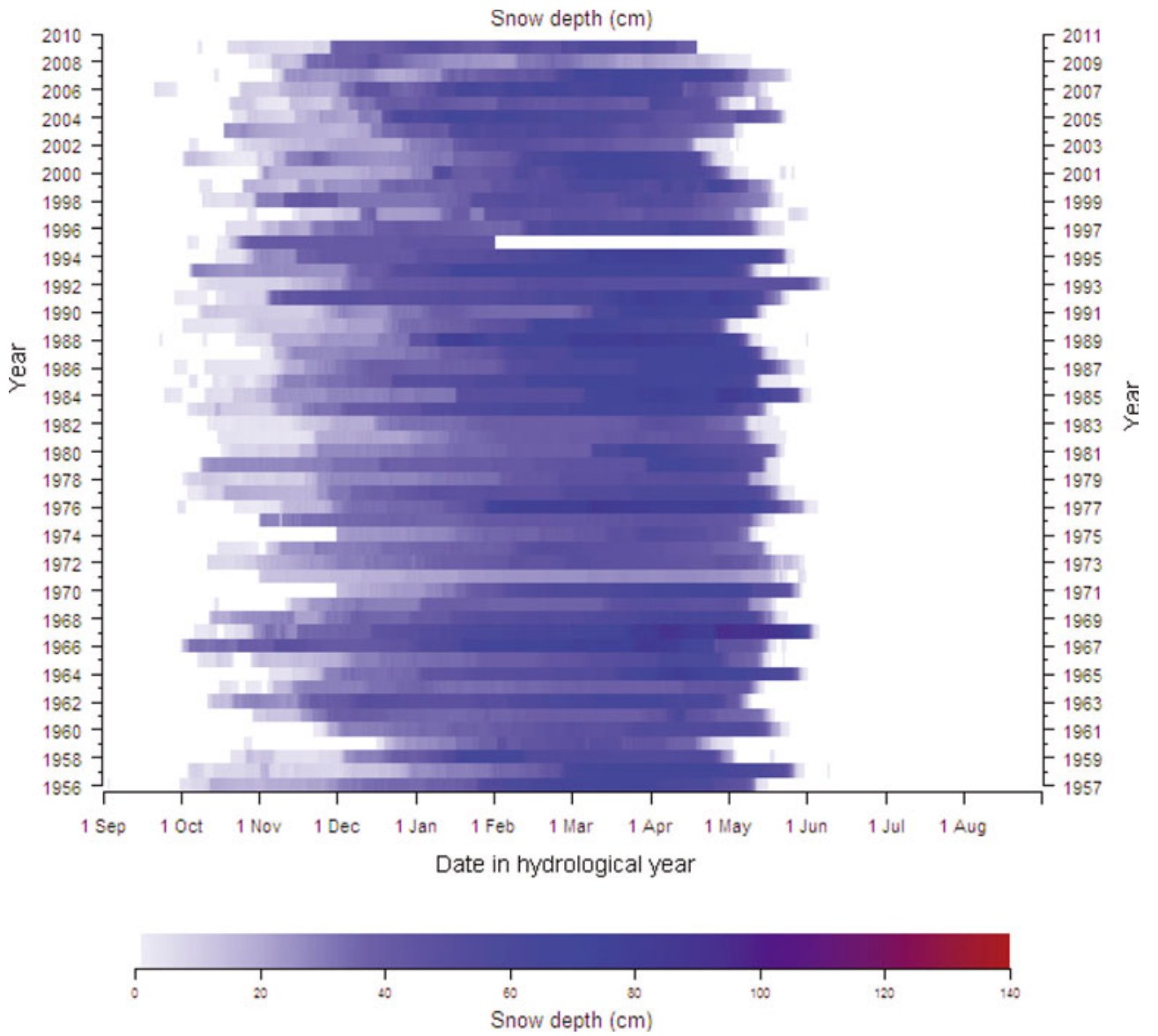

Fig. 2. Snow depth evolution in Kautokeino for the period 1956-2010. Observations are missing from January until June 1996. 


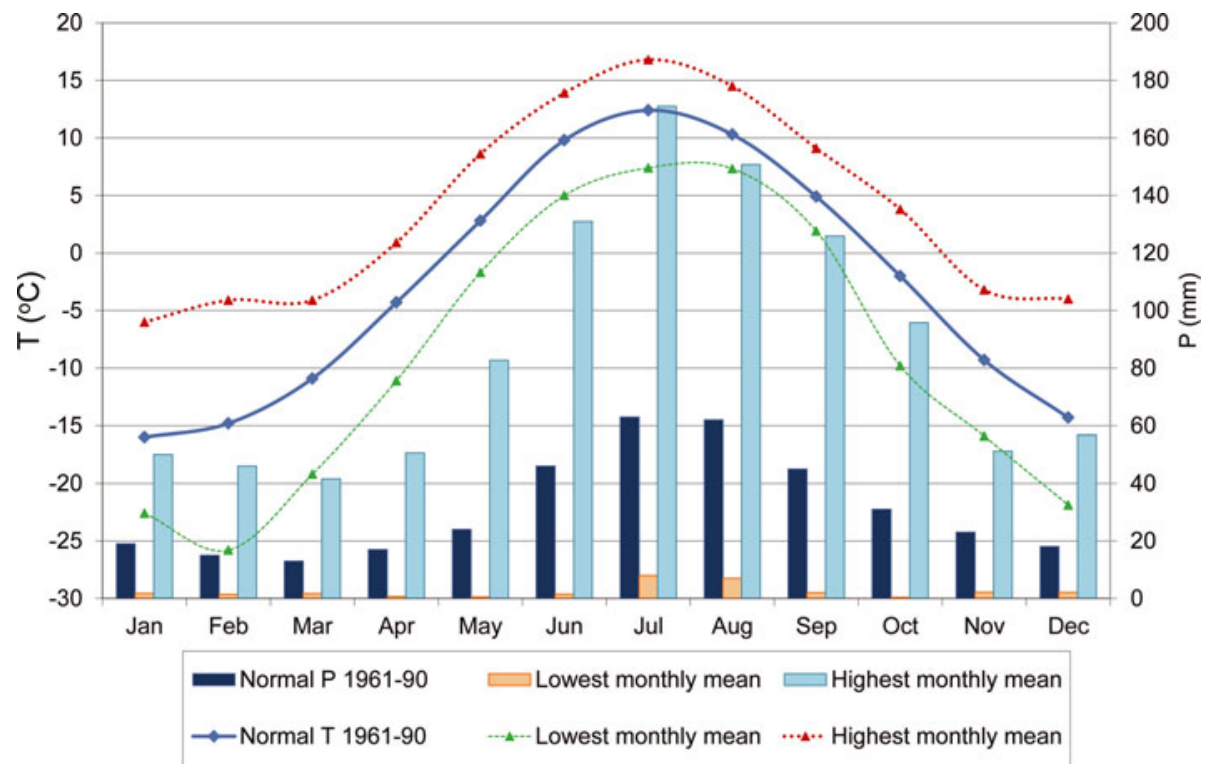

Fig. 3. The mean monthly temperature and precipitation sums for the standard normal period 1961-90, and the highest and lowest monthly means measured in Kautokeino in the same period.

it should be noted that reindeer-herding regions in northern Asia are usually even colder during winter, and winter precipitation is even more limited in some of those regions (Vikhamar-Schuler and others, 2010b).

Available meteorological data from Kautokeino are described in Sections 4.1 and 4.2 and show considerable interannual variability. Figure 3 presents the mean monthly temperature and precipitation for the standard normal period 1961-90 for Kautokeino, as well as the highest and lowest monthly means measured in the same period. The average winter temperature is $\sim-15^{\circ} \mathrm{C}$. Monthly mean values ranging from -5 to $-25^{\circ} \mathrm{C}$ have been recorded during winter. The driest part of the year is usually winter and early spring, when mean monthly precipitation is $<20 \mathrm{~mm}$. Monthly precipitation sums ranging from $<1 \mathrm{~mm}$ to $>50 \mathrm{~mm}$ have been recorded in these months during the period 1900-2011. The highest monthly values for temperature $\left(12.4^{\circ} \mathrm{C}\right)$ and precipitation sum $(63 \mathrm{~mm})$ are found during summer (July). The recorded monthly temperature variation is smaller in summer than in winter.

The variability in daily weather conditions in Kautokeino is only to a limited degree reflected in the monthly mean values. For example, in spite of the continental winter climate, days with temperature above zero may occur even in midwinter, and precipitation as rain has been recorded in all months of the year (Vikhamar-Schuler and others, 2010a).

\section{DATA}

\subsection{Long-term climate data}

We applied official meteorological data from Kautokeino, freely available from the Norwegian Meteorological Institute (www.eklima.no), for describing the climate in Kautokeino, for characterizing the weather conditions in specific years and as driving data for the snow model. The detailed daily observations required by the snow model are available only from 1956. These data are further described in Section 4.2. For characterizing the climate in Kautokeino in a longer time perspective, monthly temperature and precipitation records were applied. These are available from observations started in Kautokeino late in the 19th century. In the present analyses we used these monthly series from 1900 to 2011.

The monthly records of temperature and precipitation are not complete. Furthermore, the station was twice relocated: in 1970, when it was moved from the valley bottom (307 ma.s.l.) to the valley side (330 ma.s.l.), and in 1996 when it was moved back to its original site. In the official data archives, no correction has been made for possible homogeneity errors (Nordli, 1997). Both homogeneity considerations and gap filling are thus demanded. The winter temperature is expected to be slightly higher at the valley side than in the valley bottom, because of frequent temperature inversions in winter. This is in accordance with the 1961-90 climatology for the two localities, as the difference between the mean monthly temperatures at these stations is $0.2^{\circ} \mathrm{C}$ or less in the period May-November, while the former site is systematically $0.2-0.5^{\circ} \mathrm{C}$ colder in December and January through April (Aune, 1993). Though these differences might affect long-term trend analyses, they are of little relevance from a climate variability perspective (Fig. 3). We therefore merge the temperature series from the two localities without adjustments.

For precipitation, climatological differences between the two measuring sites are expected to be minor. However, very low values of winter precipitation prior to 1970 motivated a comparison of the series from Kautokeino with regional precipitation series valid for inland Finnmark, which are based on several precipitation series in the area (Hanssen-Bauer, 2005). The comparison revealed no change with respect to the regional series in 1996, but a large change from 1970 to 1971, when winter precipitation in Kautokeino increased abruptly compared to the regional curve. The reason for this is probably not the relocation of the station, but rather a windscreen which was introduced at the same time, leading to increased catch efficiency of the precipitation gauge. Adjustment factors for different months were calculated based on the ratio between the Kautokeino series and the regional series after and before the change (Table 1). In winter, the adjustment factors are considerable, 
Table 1. Adjustment factors used on monthly precipitation sums from Kautokeino before autumn 1970

Jan Feb Mar Apr May Jun Jul Aug Sep Oct Nov Dec $\begin{array}{llllllllllll}1.75 & 1.75 & 1.65 & 1.1 & 1 & 1 & 1 & 1 & 1 & 1 & 1.1 & 1.4\end{array}$

which is consistent with the fact that a windscreen would affect snow far more than rain. In the present study, we homogenized the monthly precipitation series by multiplying values from before autumn 1970 with the factors given in Table 1.

Both for temperature and precipitation, the valid regional series were used to fill gaps in the monthly Kautokeino series following the method described by Hanssen-Bauer (2005).

\subsection{Driving data for the SNOWPACK model}

The model was run for time series of observations digitally available from 1956 until 2010 (Table 2). All observations (precipitation, temperature, relative humidity, wind speed, wind direction and cloud cover) are recorded at 00:00, 06:00, 12:00 and 18:00 UTC, while snow depth is observed daily at 06:00.

Snow surface temperature, ground surface temperature and radiation are not routinely observed at the weather station, but are required input parameters for the SNOWPACK model. We used the Neumann boundary conditions for the runs to describe the heat flux between snow surface and atmosphere. Incoming longwave radiation was estimated by the model using observed cloudiness from the weather station, while we computed the potential incoming shortwave radiation using the method described by Hock (1999). The method computes the daily and seasonal cyclicity in clear-sky direct solar radiation based on latitude, longitude and surrounding topography. We computed the potential shortwave radiation for a point (weather station) on a flat surface.

Ground surface temperature below the snowpack has not been measured over the model period (1956-2011) but is required by SNOWPACK as a boundary condition at the lower end of the domain. In the absence of such measurements, the ground surface has been assumed to be $0^{\circ} \mathrm{C}$ (Rasmus and others, 2007). This assumption is not valid for the Kautokeino region, as indicated by the presence of discontinuous and sporadic permafrost conditions (Fig. 1) (Isaksen and others, 2008; Christiansen and others, 2010). Here we derive the ground surface temperature from available observations of air temperature $T_{\text {air }}$ and snow depth SD by convolution of the temperature series with a transfer function $\Phi$ depending on SD:

$$
\Phi(\mathrm{SD}, t)=\frac{\mathrm{SD}}{\sqrt{4 \pi \kappa t^{3}}} \exp \left(-\frac{\mathrm{SD}^{2}}{4 \kappa t}\right) .
$$

Here $t$ denotes time, and the transfer function describes purely conductive heat transport through a semi-infinite medium having uniform thermal properties in terms of heat diffusivity $\kappa$ (Carslaw and Jaeger, 1986).

For the snow depth, precipitation or snow depth may be used as model input for driving SNOWPACK. If precipitation is applied as driving data, the snow depth is computed, while the use of observed snow depth directly gives accurate snow depth. We used observed snow depth as model input in our application. In this operation mode, precipitation
Table 2. Driving data for SNOWPACK from the Kautokeino weather station

\begin{tabular}{lcc}
\hline & Description & Unit \\
\hline Air temperature & $2 \mathrm{~m}$ & ${ }^{\circ} \mathrm{C}$ \\
Relative air humidity & $2 \mathrm{~m}$ & $\%$ \\
Precipitation & $2 \mathrm{~m}$ & $\mathrm{~mm}$ \\
Wind speed & $10 \mathrm{~m}$ & $\mathrm{~m} \mathrm{~s}^{-1}$ \\
Wind direction & $10 \mathrm{~m}$ & ${ }^{\circ}$ \\
Snow depth & - & $\mathrm{cm}$ \\
Cloud cover & - & $1-8$ \\
\hline
\end{tabular}

input is still required to characterize rain events, which may lead to ground-ice and crust formation.

The SNOWPACK model simulates the evolution of layer stratigraphy for specified time-steps. Each layer is described by physical properties, i.e. liquid water content, grain type, grain size, density, temperature and depth. In our application we focus on identifying high-density snow layers which may have contributed to difficult grazing conditions. For this purpose we post-processed the output from SNOWPACK. For each time-step we identified layers having snow density above a specified threshold (tentatively $350 \mathrm{~kg} \mathrm{~m}^{-3}$ ). The thicknesses of these layers were summed and visualized for each individual winter from 1956 to 2010 (Figs 6 and 7). These plots represent a new approach to identify possible unfavourable grazing years due to ice conditions or hard layers in the snow.

\subsection{Validation and evaluation data}

We distinguish between model validation and model evaluation. By model validation we mean the assessment of the model's ability to reproduce observed physical structures within the snow layer. To validate our snow model results, we used two different sources: (1) hourly intra-snowpack temperature measurements at Kautokeino and (2) twice-monthly snow profile measurements which describe the physical properties of the snowpack, from winter 2009/10. The snow temperature was measured at three different heights above ground $(0,10$ and $35 \mathrm{~cm})$ using Campbell Scientific 109 probes, based on BetaTherm $10 \mathrm{~K} 3 \mathrm{~A} 11 \mathrm{~B}$ Thermistors (tolerance: $\pm 0.2^{\circ} \mathrm{C}$ ), and the data were recorded on a Campbell Scientific CR200 data logger. For practical reasons, the station was located at an undisturbed place in the vicinity of Sami University College, Kautokeino. It is referred to here as the EALAT station, and vertical snow profiles were collected twice a month at this location. These observations include identification of snow layers and measurements of their physical properties (snow density, grain type, temperature, resistance, photographies).

We use the term model evaluation to denote the assessment of the model's ability to identify periods when snow conditions were problematic according to the reindeer herders. The evaluation data therefore consist of records of 'difficult winters' with respect to reindeer husbandry in the Finnmark region. There is a limited amount of literature dealing with this kind of detailed historical information. Tyler and others (2007) described just a few examples of winters when climate conditions at the Finnmark plateau were, in different ways, unfavourable for reindeer herding. Lie and others (2008) included a more systematic analysis of years characterized as 'difficult' during the period 1953-2006. 
Table 3. Historical records of unfavourable winters for reindeer grazing in Finnmark. The information includes snow and weather conditions and possible causes of the problems. Winters in bold type represent years that contributed high reindeer losses

\begin{tabular}{|c|c|c|}
\hline Period & Ice conditions & Description \\
\hline 1917/18 & Ground ice conditions & $\begin{array}{l}\text { 'So extreme were ground ice conditions in the winter of } 1917 / 18 \text {, for example, that some Saami herders } \\
\text { in Finnmark abandoned, or never even entered, the winter pastures and took their herds out to summer } \\
\text { pastures at the coast where the same mild conditions that created the ice had left the ground bare' (Tyler } \\
\text { and others, 2007). }\end{array}$ \\
\hline 1930s & & $\begin{array}{l}\text { Warm wet winters. 'Conditions became difficult owing to heavy precipitation, herds were spread out } \\
\text { and moved to summer pastures at the coast earlier than normal in spring' (Tyler and others, 2007). }\end{array}$ \\
\hline $1954 / 55$ & Ice layers at snow surface & Bad weather during late winter and spring (Lie and others, 2008). \\
\hline $1955 / 56$ & Ice conditions & Ice conditions in the snowpack throughout the winter. Warm spring temperatures (Lie and others, 2008). \\
\hline $1957 / 58$ & Ice conditions & Snow layers with high density formed after new year. Normal spring conditions (Lie and others, 2008). \\
\hline $1958 / 59$ & Ice conditions & Warm midwinter, cold late winter. Normal spring conditions (Lie and others, 2008). \\
\hline $1961 / 62$ & Ground ice conditions & $\begin{array}{l}\text { Warm weather events in December 1961, followed by extreme cold, created ice conditions both on the } \\
\text { ground and the snow surface. Low spring temperatures resulted in late snowmelt (Lie and others, 2008). }\end{array}$ \\
\hline $1965 / 66$ & Ice conditions & Cold late-winter conditions (Lie and others, 2008). \\
\hline 1966/67 & & $\begin{array}{c}\text { Cold summer and early start of snow season. Cold midwinter. Large percentage of the reindeer did not } \\
\text { calve (Lie and others, 2008). }\end{array}$ \\
\hline $1967 / 68$ & Ground ice conditions & $\begin{array}{l}\text { ROS events followed by extreme cold created ground ice conditions during November } 1967 \text {. Large } \\
\text { amounts of snow combined with persistent cold throughout winter was followed by late snowmelt } \\
\text { season (Tyler and others, 2007; Lie and others, 2008). }\end{array}$ \\
\hline 1996/97 & Ground ice conditions & Large amounts of snow (Lie and others, 2008). \\
\hline 1989/90 & & $\begin{array}{c}\text { Warm midwinter. Highest number of reindeer ever in Finnmark. Difficult grazing conditions (Lie and } \\
\text { others, 2008). }\end{array}$ \\
\hline 1991/92 & & $\begin{array}{l}\text { Much precipitation in autumn, warm midwinter. Loss of }>10 \% \text { of adult reindeer in western Finnmark } \\
\text { (Lie and others, 2008). }\end{array}$ \\
\hline 2000/01 & & Large amounts of snow (Lie and others, 2008). \\
\hline
\end{tabular}

Their main sources were annual reports from the regional reindeer management areas, oral accounts from herders and managers, and statistics on reindeer losses. Since 1980 the reports from the management regions have provided less detailed information. On the other hand, the statistics on losses have been more complete. The historical record of winters with unfavourable conditions is presented in Table 3.

\section{RESULTS}

\subsection{Long-term climate analysis}

The literature-based overview of known years with unfavourable winter conditions for reindeer herding in western Finnmark during the last 100 years (Table 3 ) includes 13 specific winters in addition to the unspecified '1930s'. Ten of the problem winters occurred after 1955, in the period covered by the snow modelling. Layers of ice or high-density snow are the most frequently mentioned problems. The formation and duration of such layers depend to a large degree on the combination of precipitation and temperature conditions throughout autumn, winter and spring. Tyler and others (2007) used plots of seasonal temperature and precipitation anomalies to illustrate the large climate variability in Finnmark. We computed a similar plot for the 3 month period December-February in Kautokeino for the years 1900-2011 (Fig. 4). The analysis shows that precipitation varied between $20 \%$ and $200 \%$ of the $1961-90$ climatology, while the average 3 month temperature variability was up to $\pm 7^{\circ} \mathrm{C}$ relative to climatology. The same interannual variability was observed in our climate analysis plots covering the other 3 month periods September-November (autumn) and March-May (spring) in Kautokeino (plots not shown).

In these plots, the outlier years represent four types of extraordinary winters: (1) dry, cold winters (lower left), (2) wet, cold winters (upper left), (3) wet, warm winters (upper right) and (4) dry, warm winters (lower right). Note that the 13 'problem seasons' do not reveal a systematic pattern within the plot, whereas the 'problem seasons' tend to appear in the middle of the plot (Fig. 4). As such, difficult grazing conditions are not necessarily associated with outliers in the precipitation-temperature space for the three analysed 3 month periods. However, both the coldest and warmest winters are recorded among the difficult winters. This shows that unfavourable conditions are not easily identified from mean values. It also indicates that unfavourable conditions may develop in different ways. The reindeer herders divide the period September-May into shorter periods referred to as 'autumn', 'autumn-winter', 'winter', 'spring-winter' and 'spring' (Lie and others, 2008). However, even monthly resolution of temperature and precipitation anomalies (not shown) does not reveal a systematic pattern of the problematic years, such as we can see in Figure 4.

\subsection{SNOWPACK model results}

\subsubsection{Validation against snow measurements}

Can we use the multilayer snow model to identify highdensity layers? The intra-snowpack temperature measurements and snow stratigraphic observations show very promising results. Although the snow observations at the EALAT station were carried out at a few kilometres distance from the official weather station (referred to as the met.no station), both stations have practically the same weather and snow conditions. We used the observations from the EALAT station to validate the modelling results from the met.no station. The $r^{2}$ coefficient of determination for hourly observed $2 \mathrm{~m}$ air temperatures at the two stations is 0.97 . Only for extremely low temperatures does the met.no station record significantly lower temperatures, which might be an effect of temperature inversions in the winter or a stronger local cold air pool. Observed snow depth on six occasions 


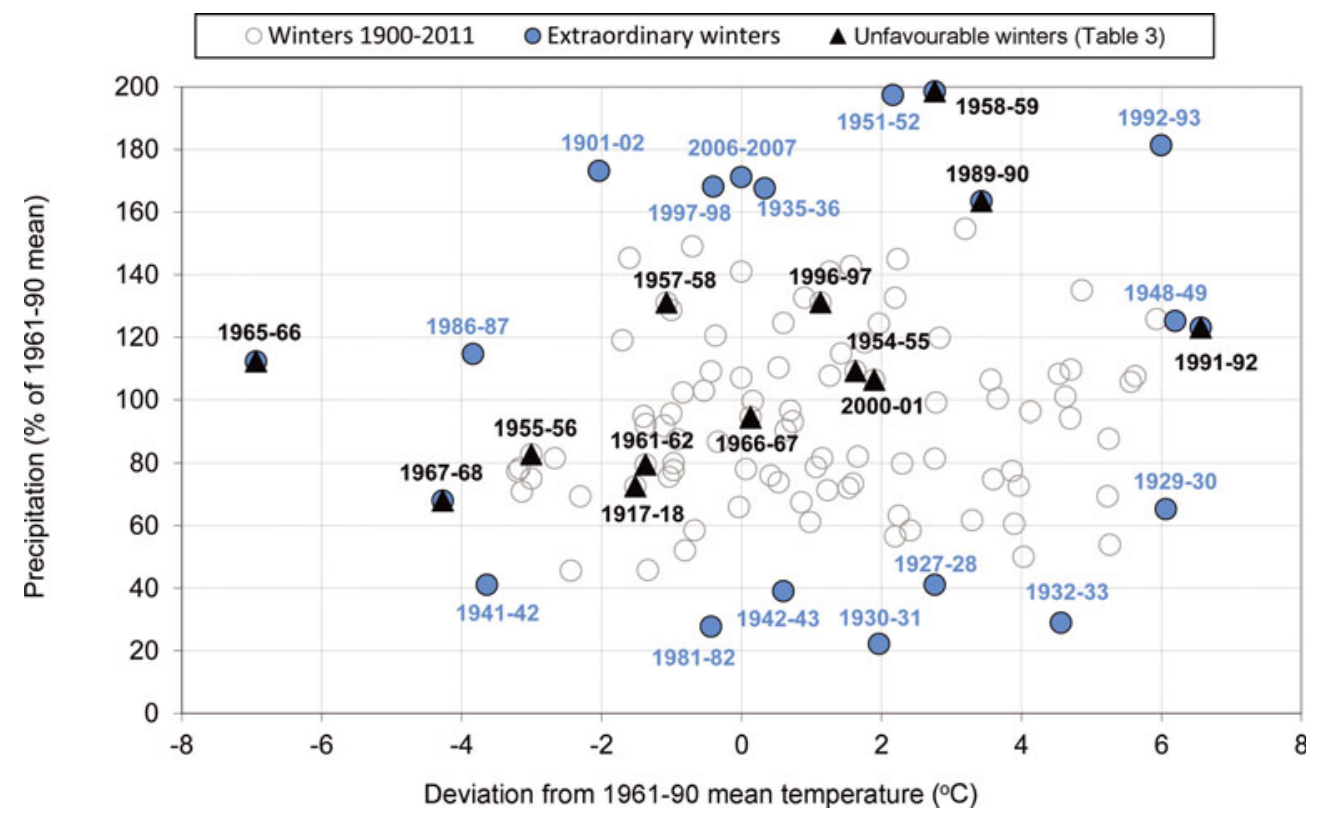

Fig. 4. Scatter plot of seasonal mean temperature and precipitation sum from 1900 to 2011 for winter (December-February) in Kautokeino. Extraordinary winters in the precipitation-temperature space are presented as filled blue circles, and unfavourable winter grazing years mentioned in the text are identified with filled triangles. Temperatures are given as anomalies from the $1961-90$ mean $\left(-15^{\circ} \mathrm{C}\right)$, and precipitation is given as a percentage of the 1961-90 mean precipitation sum for December-February (43 mm).

in 2010 (15 January, 22 January, 11 February, 1 March, 29 March and 13 April) varied only within $10 \mathrm{~cm}$ at the two locations.

The observed and modelled snow temperatures were compared at $0 \mathrm{~cm}, 10 \mathrm{~cm}$ (Fig. 5a) and $35 \mathrm{~cm}$ (Fig. 5b) heights above the ground. Validation is performed for the days when the snow thickness (HS, following the definition by Fierz and others, 2009) exceeded the height of the temperature sensors by $>15 \mathrm{~cm}$. Figure $5 \mathrm{a}$ and $\mathrm{b}$ both show that the snow temperature is modelled with too low temperatures, with an increasing deviation at lower temperatures. This may be related to the atmospheric stability corrections applied in SNOWPACK, which will lead to underestimated snow surface temperature, and therefore also internal temperatures in case of low-wind, fair-weather conditions. A roughness length of $2 \mathrm{~mm}$ may also have contributed to the underestimation of surface temperatures for clear nights. A systematic investigation of the effect of roughness length was not carried out, but this should be included in a future study. For temperatures around $0-5^{\circ} \mathrm{C}$, there are small deviations between the observed and modelled values, and this temperature range is also most important for snow metamorphoses, melt processes and possible ice layer formation. For days with shallow snow cover $(\mathrm{HS}<10 \mathrm{~cm})$, the results show that the snow temperature was modelled slightly higher than the observed temperature at the ground surface. This may be due to the observed differences in snow depth at the two stations. Overall, we conclude that the SNOWPACK model can be used for our purpose.
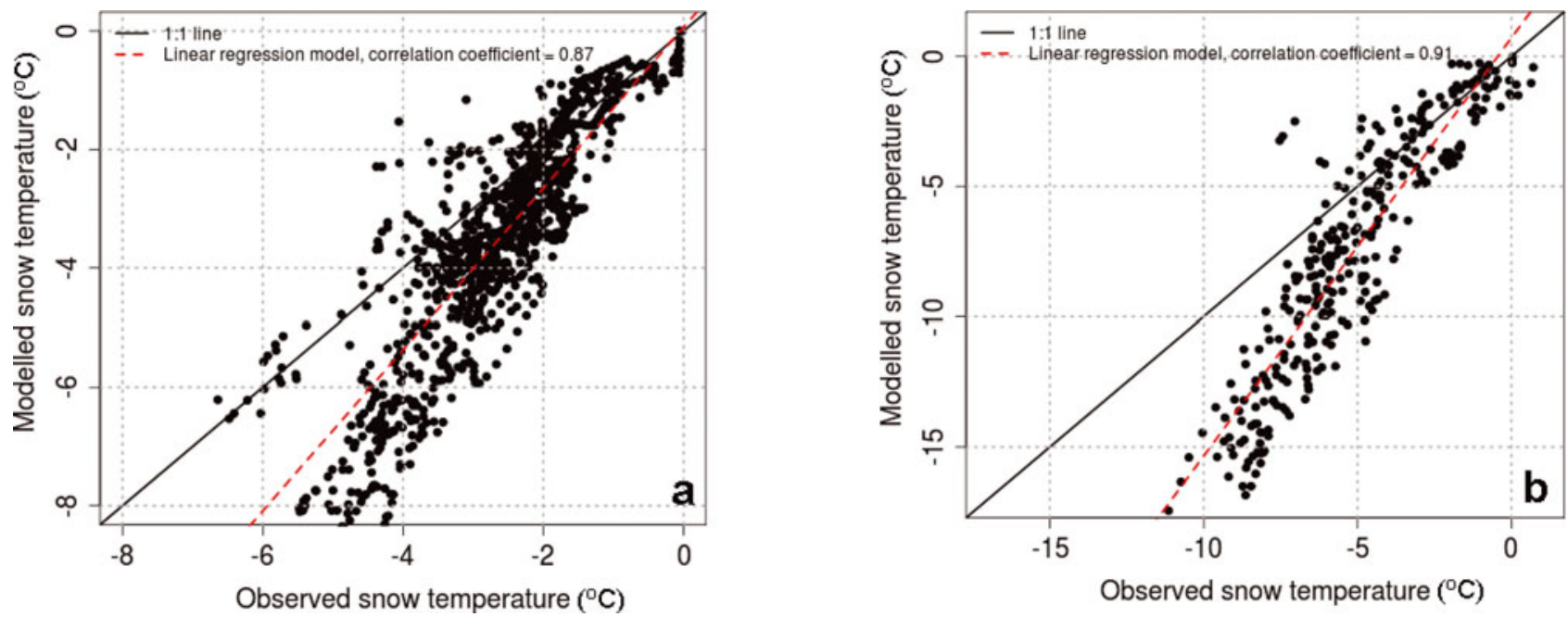

Fig. 5. Comparison of observed snow temperatures from the EALAT station and modelled snow temperatures from the SNOWPACK model for the period 22 October 2009 to 13 April 2010: (a) snow temperature at $10 \mathrm{~cm}$ height above the ground, for days with HS > $25 \mathrm{~cm}$; (b) snow temperature at $35 \mathrm{~cm}$ height above the ground, for days with $\mathrm{HS}>50 \mathrm{~cm}$. 

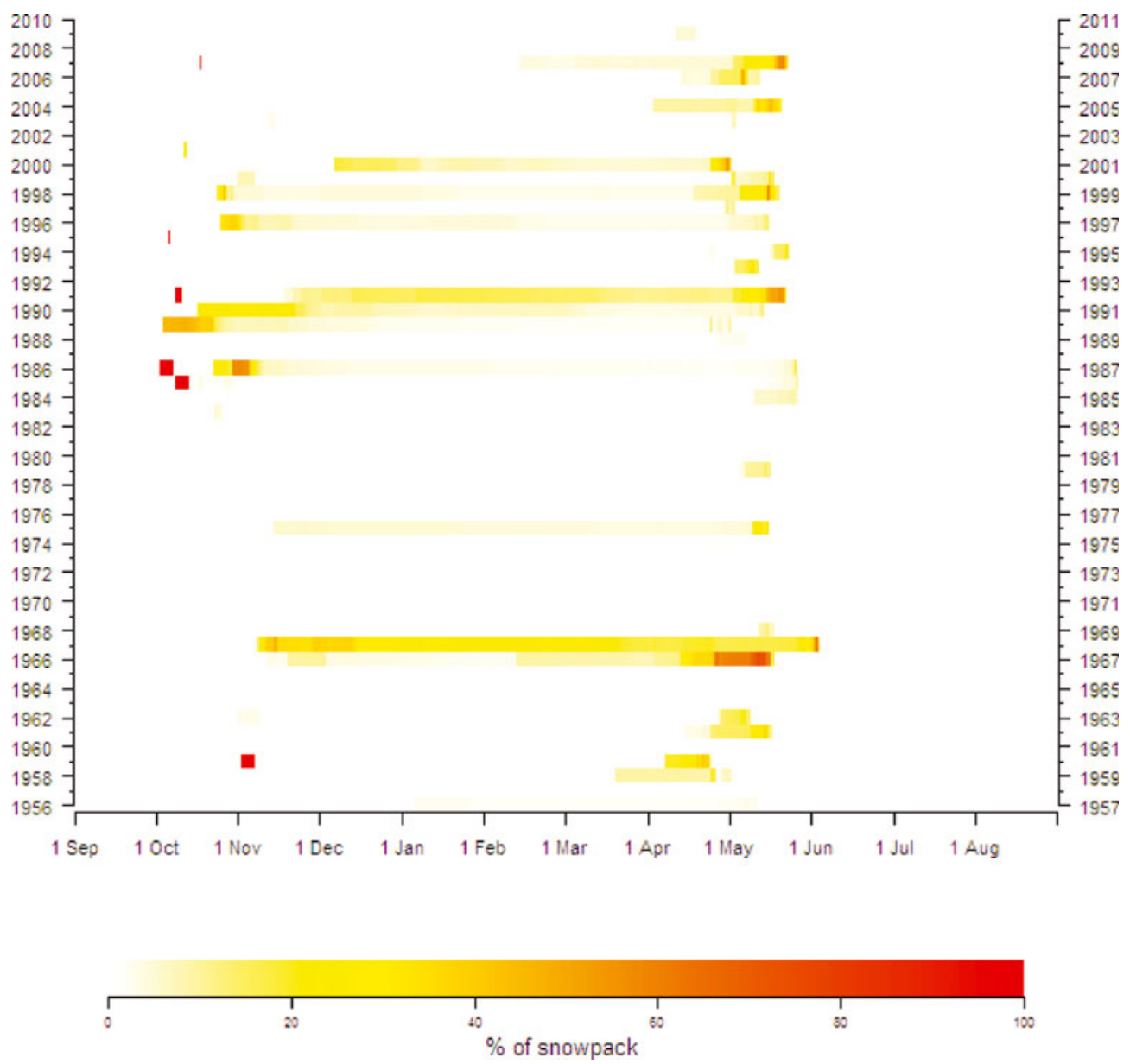

Fig. 6. Percentage of total snow depth having density above $350 \mathrm{~kg} \mathrm{~m}^{-3}$ for the hydrological years $1956-2010$ (1 September-31 August).

5.2.2. Modeled high-density snow layers 1956-2010 The SNOWPACK simulations were conducted for the years 1956-2010 at 6 hour intervals and therefore resolve the processes leading to difficult winter grazing conditions such as melt-refreeze cycles. The output should thus show snowcover development throughout the season, including effects of possible short-period extreme temperature or precipitation events. Figures 6 and 7 give an overview of the calculated amounts of snow with density above a threshold value (set to $350 \mathrm{~kg} \mathrm{~m}^{-3}$ ) from autumn to spring in all years during this period. According to the model, both the relative amounts of such dense layers (Fig. 6) and their absolute vertical extent (Fig. 7) varied widely throughout the season as well as between years. For several winters during the 1970s and 1980s, no such layers were simulated by the model. On the other hand, the years 1966/67, 1967/68 and $1991 / 92$ according to the model had $10 \mathrm{~cm}$ or more of dense snow layers at least from December to May. These features fit well with the historical record of difficult winter grazing conditions (Table 3). While few climate-related problems were reported in the 1970s and 1980s, all three years with extensive modelled high-density layers are among the reported problem years. In fact 1966/67 and 1967/68 were reported to be among the five most problematic winters in the modelling period. The 1967/68 winter was famously a catastrophic one for reindeer husbandry (Tyler and others, 2007). According to Lie and others (2008), one has to go back to 1917 to find similar losses of reindeer. The output of SNOWPACK also indicates that $1967 / 68$ is the most extreme of the modelled winters, as a substantial high-density layer formed as early as November and lasted until July (Fig. 8a and b). The model simulations from November 1967 demonstrate how a 'warming event' (ROS event) followed by extreme cold formed a high-density layer.

For the other years within the modelling period that were reported to have especially unfavourable winter conditions (1961/62, 1996/97 and 2000/01), the model indicates the existence of dense snow layers, though not as extensive and long-lasting as in the three above-mentioned years. Another five winters within the modelling period were also reported to be difficult. For two of these (1957/58 and 1965/66) the model does not simulate high-density snow layers (Figs 6 and 7), though 'ice conditions' are reported in Table 3.

There are also some years when the model results indicate formation of some high-density snow layers, but when no problems were reported. For the years since 1980, the fact that the reporting of grazing conditions has been less systematic (Lie and others, 2008) may explain some discrepancies between the model results and Table 3 . However, the model also simulated high-density snow layers for the 1960/61, 1962/63 and 1975/76 winters, which are not reported to have been problematic.

Altogether, the model results indicated possible ice problems in eight of the ten reported 'problem years', and in all those reported as most problematic. From 1956/57 to 2006/07 there are also 30 winters when neither the model nor the information summarized in Table 3 indicates problems connected to snow conditions. However, in two 

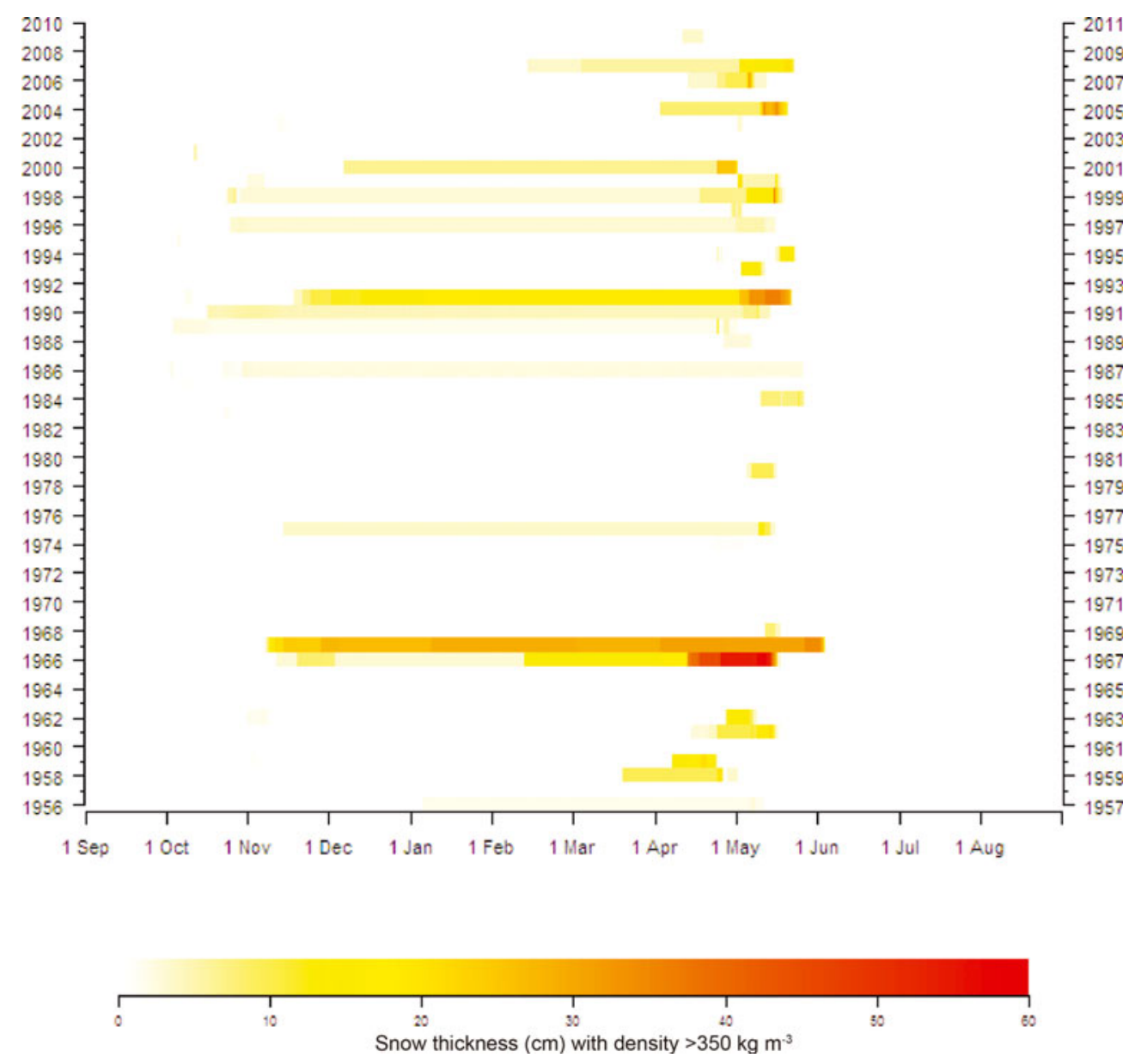

Fig. 7. Sum (cm) of vertical extent of layers having density above $350 \mathrm{~kg} \mathrm{~m}^{-3}$ for hydrological years $1956-2010$ (1 September-31 August).

years the model failed to simulate ice layers though they were reported ('failed detection'), and it also indicated some ice layers in nine years when no problems were reported ('false alarms'). In the discussion we take a closer look at the model performance and uncertainties related to the categories 'false alarms' and 'failed detection'.

\section{DISCUSSION}

\subsection{Why the climate data analysis does not identify unfavourable winter conditions}

Results of the climate data analysis demonstrate that processes leading to high-density snow layers occur on timescales that are not resolved by monthly values. There are at least two reasons why the unfavourable seasons do not show a clear signature in Figure 4. First, seasonal or even monthly means do not necessarily capture extreme events. For instance, the mean temperature for December 1961 was far below the 1961-90 average. Nevertheless, there was a 'warming event' in that month, with temperatures above $0^{\circ} \mathrm{C}$. If followed by extreme cold, such events may lead to the formation of ice layers in the snow. Although high mean values of the temperature during winter months probably imply increased frequency of warming events, such events may also occur in generally cold periods. Secondly, whether or not given seasonal conditions are unfavourable for reindeer may depend on the previous and/or following season. A cold spring may be unproblematic after a reasonably dry winter with easily available pastures, but if heavy ice layers have formed during autumn or winter, a cold spring may be catastrophic (Lie and others, 2008).

\subsection{Why the SNOWPACK model identifies many of the documented unfavourable winters during 1956- 2010}

Overall, the model simulations of winters with high-density layers correspond quite well with the historically reported winters. There are several advantages of using a physical snow model such as SNOWPACK in comparison to a climate data analysis. The physical snow model applied available meteorological data observed at 6 hour intervals as driving data. This time resolution allows modelling of the physical processes (warming events and ROS events) that lead to formation of high-density snow layers. These processes are not captured by a climate data analysis of monthly values. There is still a question whether the 6 hour time resolution of the meteorological data is enough to identify the warming events usually leading to the ice-layer formation. The simulations using the SNOWPACK model include both a high-resolution dataset and the snow process modelling. A future study could focus on distinguishing these two effects. However, the snow process simulations also allow us to study where in the snowpack ice layers or high-density layers appear, which would be impossible using only meteorological data of high time resolution. The SNOWPACK model also simulates grain types, such as depth hoar. Depth hoar consists of large faceted grains which are very poorly bonded and therefore advantageous for winter grazing conditions. The validation data from the 

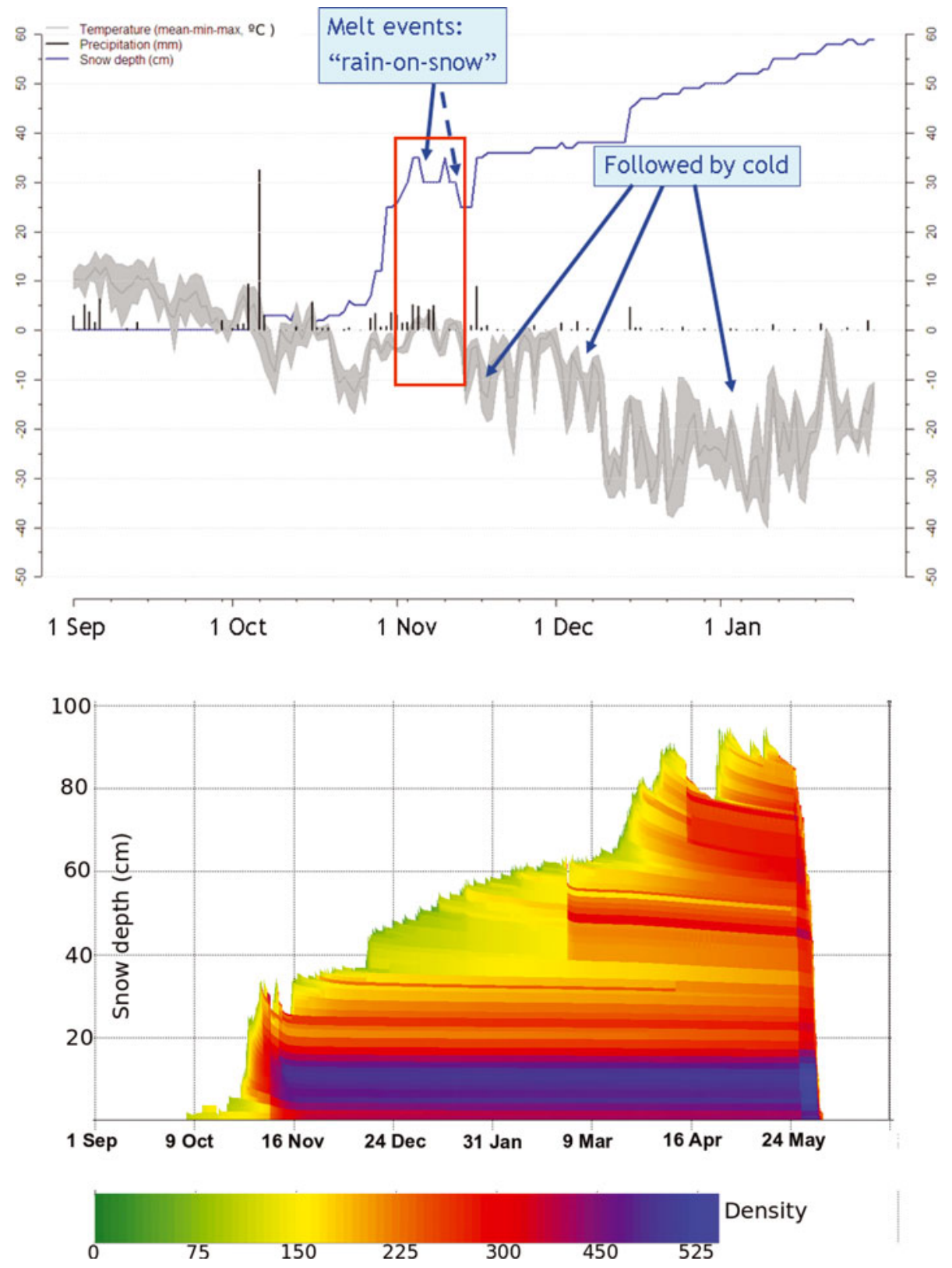

Fig. 8. The difficult grazing winter 1967/68 in Kautokeino. The ROS event in November 1967 formed a high-density snow layer that persisted throughout the winter.

Finnmark region did not contain extensive and detailed information on this matter. In a future study, however, observations of ice layers and depth hoar would be a very useful dataset for detailed model validation.

In the simulations a threshold of $350 \mathrm{~kg} \mathrm{~m}^{-3}$ was applied to sum up the vertical extent of the high-density layers. This threshold is empirical and should be regarded as a relative measure. With available ice-layer observations it could be set more specifically.

In our approach for deriving ground surface temperature below the snowpack, the thermal diffusivity $\kappa$ represents the bulk diffusivity of snow, averaged over the season, and we adopted $\kappa=10^{-7} \mathrm{~m}^{2} \mathrm{~s}^{-1}$. This method has previously been used to quantify the thermal dynamics of permafrost and found to be valuable for negligible heat production, i.e. for relatively dry sites with little water available (Roth and Boike, 2001). That we capture the temperature dynamics at the snow/soil interface with this approach is a strong assumption, which may be the cause of some of the simulation errors. In the future, we could include the soil layers below the snow in the SNOWPACK simulations and use an assumed constant geothermal heat flux at some depth to better represent the soil/snow interface.

\subsection{On false alarms and failed detections}

The validation of the snow density simulations against the historical records of difficult winter grazing conditions (Table 3) revealed a few 'false alarms' and 'failed detections'. 'False alarm' represents a winter where the model simulations identify high-density snow layers, while the annual report from the Sami Reindeer Management in Norway does not contain information about difficult snow conditions. 'Failed detection' represents the other case, where the annual report contains description of difficult winter grazing conditions while the model simulations do not identify high-density snow layers. There are several possible causes for these errors. First of all we have modelled the situation in Kautokeino, or, more precisely, 
the location of the weather station in Kautokeino. The simulations are only valid for this location. However, we assume that this point is representative of a larger region, using the historical records as validation data. The annual reports cover the weather and snow conditions over the entire Finnmark plateau. As such, the conditions in Kautokeino may be good while the conditions were difficult in other areas of Finnmark. The spatial variability of snow depth and its layer densities is probably quite large. As such, this spatial variability is not captured when modelling a single point. A future study should therefore contain several stations to improve the representation of the region. Since the historical literature records are inadequate and nonsystematic over time, reports from northern Sweden support the information in Table 3. Päiviö (2006) describes historical winter grazing conditions leading to catastrophic years for reindeer herding in the Jokkmokk region. He reports 1967/ 68 as a catastrophic year for reindeer herding, in addition to the 1935/36 and 1955/56 winters. Furthermore, he describes the second part of the 1970s and the entire 1980s as years with favourable winter grazing conditions, while conditions in the 1990s were unfavourable.

Other reasons for the 'false alarms' and 'failed detections' may be a combination of factors occurring within a year. For instance, difficult summer grazing conditions lead to a reindeer population of weak animals, even before the start of the winter. A cold summer, followed by a winter with large amounts of snow, may therefore also represent difficult winter grazing conditions not captured by the model simulations, when only snow density is studied. However, by analysing combined factors, 'failed detections' may be reduced. Another cause of 'false alarms' or 'failed detections' is the reindeer-herding aspect. A reported non-difficult year may in fact have had difficult snow conditions, or areas with ground ice layers, but the reindeer herders acted wisely by moving their animals to better grazing areas, and thereby avoided losses of animals.

\section{SUMMARY AND CONCLUSIONS}

We have compared the performance of two different methods for identifying winters reported to have been difficult for the reindeer population in the past in Kautokeino.

The long-term climate data analysis based on monthly values of precipitation and temperature (1900-2011) demonstrated that the reported winters were difficult to identify systematically. These are generally not extreme winters with regard to monthly or 3 monthly mean values.

The physical snow model SNOWPACK successfully simulates high-density snow layers in eight of the ten reported difficult winters during the period 1956-2010. The time resolution of the driving data ( 6 hours) allows modelling of the physical processes (warming events and ROS events) leading to formation of high-density snow layers.

The model simulations indicate that $1967 / 68$ is the most extreme winter in terms of high-density snow layers. During the modelling period 1956-2010, this winter is reported as the most catastrophic for reindeer husbandry, with considerable losses of animals caused by groundice layers in conjunction with long snow-cover duration (Tyler and others, 2007).
For several winters during the 1970s and 1980s, no highdensity snow layers were simulated by the model, and this is consistent with the literature records.

The analysis revealed a few 'false alarms' and 'failed detections'. These are related to different types of uncertainties in the modelling and the validation data.

There is no systematic reporting of causes (snow conditions, ice layers, spatial extent, human action) of losses of animals during the period 1956-2010. There are also no measurements of ice layers available. Hence, the analysis is validated against a non-homogeneous dataset. The spatial variability of snow depth and its layer densities is probably quite large. As such, this spatial variability is not captured when modelling a single point. In addition, reported winters may also have been caused by a combination of several problematic factors (e.g. a cold summer followed by a deep, persistent snow cover).

Overall, this paper provides a new approach to the study of past snow conditions related to high-density snow layers. In a future study it will be interesting to increase the number of stations to improve representation of the spatial variability, and also carry out systematic measurements of snow densities and ice layers. This study also indicates that, if sufficiently detailed climate scenarios are available, the SNOWPACK model may be used as a tool for estimating the possible effect of global warming on conditions for reindeer husbandry.

\section{ACKNOWLEDGEMENTS}

This study was financially supported by the Research Council of Norway, project IPY (International Polar Year) EALAT-RESEARCH: Reindeer Herders Vulnerability Network Study: Reindeer Pastoralism in a Changing Climate (grant No. 76078/S30), by the Nordic Council of Ministers and by the International Centre for Reindeer Husbandry, Kautokeino, Noway. We thank Philip Burgess for establishing and maintaining the automatic weather station for recording temperatures in the snowpack in Kautokeino 2009-10. We also thank Ole Isak Eira and Ravdna B.M. Eira for providing assistance in collection of snow data. This study also received support from the Research Council of Norway, project CRYOLINK (grant No. 185987/V30).

\section{REFERENCES}

Aanes R, Sæther B-E and Øritsland NA (2000) Fluctuations of an introduced population of Svalbard reindeer: the effects of density dependence and climatic variation. Ecography, 23(4), 437-443 (doi: 10.1111/j.1600-0587.2000.tb00300.x)

Aune B (1993) Temperaturnormaler normalperiode 1961-1990. DNMI Report 02/93 Climate. Norwegian Meteorological Institute, Oslo

Bartelt P and Lehning M (2002) A physical SNOWPACK model for the Swiss avalanche warning. Part I: numerical model. Cold Reg. Sci. Technol., 35(3), 123-145 (doi: 10.1016/S0165-232X (02)00074-5)

Bellaire S, Jamieson JB and Fierz C (2011) Forcing the snow-cover model SNOWPACK with forecasted weather data. Cryosphere, 5(4), 1115-1125 (doi: 10.5194/tc-5-1115-2011)

Brun E, Martin E, Simon V, Gendre C and Coléou C (1989) An energy and mass model of snow cover suitable for operational avalanche forecasting. J. Glaciol., 35(121), 333-342 
Brun E, David P, Sudul M and Brunot G (1992) A numerical model to simulate snow-cover stratigraphy for operational avalanche forecasting. J. Glaciol., 38(128), 13-22

Brun E and 7 others (2013) Simulation of northern Eurasian local snow depth, mass and density using a detailed snowpack model and meteorological reanalysis. J. Hydromet., 14(1), 203-219 (doi: 10.1175/JHM-D-12-012.1)

Bulygina ON, Groisman PYa, Razuvaev VN and Radionov VF (2010) Snow cover basal ice layer changes over Northern Eurasia since 1966. Environ. Res. Lett., 5(1), 015004 (doi: 10.1088/1748-9326/5/1/015004)

Carslaw HS and Jaeger JC (1986) Conduction of heat in solids, 2nd edn. Oxford University Press, Oxford

Christiansen HH and 17 others (2010) The thermal state of permafrost in the Nordic area during the International Polar Year 2007-2009. Permafrost Periglac. Process., 21(2), 156-181 (doi: 10.1002/ppp.687)

Eira IMG (2012) The silent language of snow: Sámi traditional knowledge of snow in times of climate change. (PhD thesis, University of Troms $\varnothing$ )

Eira IMG, Magga OH and Eira NI (2010) North Sámi snow concepts and snow terminology: meaning and usage. Sámi diedalaš áigěcála, 2, 3-24

Eira IMG, Jaedicke C, Magga OH, Maynard NG, Vikhamar-Schuler D and Mathiesen SD (2013) Traditional Sámi snow terminology and physical snow classification - two ways of knowing. Cold Reg. Sci. Technol., 85, 117-130 (doi: 10.1016/j.coldregions. 2012.09.004)

Etchevers P and 22 others (2004) Validation of the energy budget of an alpine snowpack simulated by several snow models (SnowMIP project). Ann. Glaciol., 38, 150-158 (doi: 10.3189/ 172756404781814825)

Fierz C and 8 others. (2009) The international classification for seasonal snow on the ground. (IHP-VII Technical Documents in Hydrology 83) UNESCO-International Hydrological Programme, Paris

Forchhammer M and Boertmann D (1993) The muskoxen Ovibos moschatus in north and northeast Greenland: population trends and the influence of abiotic parameters on population dynamics. Ecography, 16(4), 299-308 (doi: 10.1111/j.16000587.1993.tb00219.x)

Hansen BB, Aanes R, Kohler IHJ and Saether BE (2011) Climate, icing, and wild arctic reindeer: past relationships and future prospects. Ecology, 92(10), 1917-1923 (doi: 10.1890/11-0095.1)

Hanssen-Bauer I (2005) Regional temperature and precipitation series for Norway: analyses of time-series updated to 2004. met.no. Report 15/2005 Climate. Norwegian Meteorological Institute, Oslo

Heggberget TM, Gaare E and Ball JP (2002) Reindeer (Rangifer tarandus) and climate change: importance of winter forage. Rangifer, 22(1), 13-31

Hirashima $\mathrm{H}$, Nishimura K, Yamaguchi S, Sato A and Lehning $M$ (2008) Avalanche forecasting in a heavy snowfall area using the snowpack model. Cold Reg. Sci. Technol., 51(2-3), 191-203 (doi: 10.1016/j.coldregions.2007.05.013)

Hock R (1999) A distributed temperature-index ice- and snowmelt model including potential direct solar radiation. J. Glaciol., 45(149), 101-111

Isaksen K, Farbrot H, Blikra LH, Johansen B, Ludvig J and Eiken T (2008) Five-year ground surface temperature measurements in Finnmark, Northern Norway. In Kane DL and Hinkel KM eds. Proceedings of the 9th International Conference on Permafrost, 29 June-3 July 2008, Fairbanks, Alaska, Vol. 1, Pt 4. Institute of Northern Engineering, University of Alaska, Fairbanks, 789-794

Johansson C, Pohjola VA, Jonasson C and Callaghan TV (2011) Multidecadal changes in snow characteristics in sub-Arctic Sweden. Ambio, 40(6), 566-574 (doi: 10.1007/s13280-011-0164-2)

Kohler J and Aanes R (2004) Effect of winter snow and ground-icing on a Svalbard reindeer population: results of a simple snowpack model. Arct. Antarct. Alp. Res., 36(3), 333-341
Kumpula J and Colpaert A (2003) Effects of weather and snow conditions on reproduction and survival of semi-domesticated reindeer (R. t. tarandus). Polar Res., 22(2), 225-233 (doi: 10.1111/j.1751-8369.2003.tb00109.x)

Lehning M and Fierz C (2008) Assessment of snow transport in avalanche terrain. Cold Reg. Sci. Technol., 51(2-3), 240-252 (doi: 10.1016/j.coldregions.2007.05.012)

Lehning $M$, Bartelt $P$, Brown B, Russi T, Stöckli $U$ and Zimmerli $M$ (1999) SNOWPACK model calculations for avalanche warning based upon a new network of weather and snow stations. Cold Reg. Sci. Technol., 30(1-3), 145-157 (doi: 10.1016/S0165232X(99)00022-1)

Lehning M, Bartelt P, Brown B, Fierz C and Satyawali P (2002a) A physical SNOWPACK model for the Swiss avalanche warning. Part II: snow microstructure. Cold Reg. Sci. Technol., 35(3), 147-167 (doi: 10.1016/S0165-232X(02)00072-1)

Lehning M, Bartelt P, Brown B and Fierz C (2002b) A physical SNOWPACK model for the Swiss avalanche warning. Part III: meteorological forcing, thin layer formation and evaluation. Cold Reg. Sci. Technol., 35(3), 169-184 (doi: 10.1016/S0165232X(02)00072-1)

Lie I, Riseth JA and Bernt H (2008) Reindrifta i et skiftende klimabilde. NORUT Alta Rapport 2008:6. Northern Research Institute, Alta

Lundy CC, Brown RL, Adams EE, Birkeland KW and Lehning M (2001) A statistical validation of the SNOWPACK model in a Montana climate. Cold Reg. Sci. Technol., 33(2-3), 237-246 (doi: 10.1016/S0165-232X(01)00038-6)

Magga O, Mathiesen SD, Corell RW and Oskal A (2011) Reindeer herding, traditional knowledge, adaptation to climate change and loss of grazing land. (Ministerial Report 1/2011) Arctic Council: Sustainable Working Group International Centre for Reindeer Husbandry, Kautokeino

Mathiesen SD and Magga OH (2011) Reindeer herders vulnerability network study: reindeer pastoralism in a changing climate. IPY EALÁT Report: Final Report to the Research Council of Norway EALAT, Kautokeino

Maynard NG and 7 others (2011) Impacts of Arctic climate and land use changes on reindeer pastoralism: indigenous knowledge and remote sensing. In Guman G and Reisel A eds. Eurasian Arctic land cover and land use in a changing climate. Springer Netherlands, Dordrecht, 177-205 (doi: 10.1007/97890-481-9118-5)

Nishimura K, Baba E, Hirashima H and Lehning M (2005) Application of SNOWPACK model to snow avalanche warning in Niseko, Japan. Cold Reg. Sci. Technol., 43(1-2), 62-70 (doi: 10.1016/j.coldregions.2005.05.007)

Nordli $\varnothing$ (1997) Homogenitetstesting av norske temperaturseriar II. DNMI Report 29/1997 Climate. Norwegian Meteorological Institute, Oslo

Päiviö NJ (2006) Sirkas sameby -om konsekvenser av beitekatastrofer. Ottar, 1, 10-17

Putkonen J and Roe G (2003) Rain-on-snow events impact soil temperatures and affect ungulate survival. Geophys. Res. Lett., 30(4), 1188 (doi: 10.1029/2002GL016326)

Rasmus S (2005) Snow pack structure characteristics in Finland: measurements and modelling. Rep. Ser. Geophys. 48

Rasmus S, Räisänen J and Lehning M (2004) Estimating snow conditions in Finland in the late 21 st century using the SNOWPACK model with regional climate scenario data as input. Ann. Glaciol., 38, 238-244 (doi: 10.3189/ 172756404781814843)

Rasmus S, Gronholm S, Lehning T, Rasmus M and Kulmala M (2007) Validation of the SNOWPACK model in five different snow zones in Finland. Boreal Environ. Res., 12(4), 467-488

Reimers E (1982) Winter mortality and population trends of reindeer on Svalbard. Arct. Alp. Res., 14(4), 295-300

Roth K and Boike J (2001) Quantifying the thermal dynamics of a permafrost site near Ny-Ålesund, Svalbard. Water Resour. Res., 37(12), 2901-2914 (doi: 10.1029/2000WR000163) 
Schirmer M, Schweizer J and Lehning M (2010) Statistical evaluation of local to regional snowpack stability using simulated snow-cover data. Cold Reg. Sci. Technol., 64(2), 110-118 (doi: 10.1016/j.coldregions.2010.04.012)

Stien A, Loe LE, Mysterud A, Severinsen T, Kohler J and Langvatn R (2010) Icing events trigger range displacement in a high-arctic ungulate. Ecology, 91(3), 915-920 (doi: 10.1890/09-0056.1)

Stössel F, Guala M, Fierz C, Manes C and Lehning M (2010) Micrometeorological and morphological observations of surface hoar dynamics on a mountain snow cover. Water Resour. Res., 46(W4), W04511 (doi: 1029/2009WR008198)

Tveito OE and 10 others (1997) Nordic precipitation maps. DNMI Report 22/1997 Climate. Norwegian Meteorological Institute, Oslo

Tveito OE and 10 others (2000) Nordic temperature maps. DNMI Report 09/2000 Climate. Norwegian Meteorological Institute, Oslo

Tveraa T, Fauchlad P, Yoccos NG, Ims RA, Aanes R and Høgda KA (2007) What regulate and limit reindeer populations in Norway? Oikos, 116(4), 706-715

Tyler NJC (2010) Climate, snow, ice, crashes, and declines in populations of reindeer and caribou (Rangifer tarandus L.). Ecol. Monogr., 80(2), 197-219 (doi: 10.1890/09-1070)

Tyler NJC and 16 others (2007) Saami reindeer pastoralism under climate change: applying a generalized framework for vulnerability studies to a sub-arctic social-ecological system. Global Environ. Change, 17(2), 191-206 (doi: 10.1016/ j.gloenvcha.2006.06.001)

Vikhamar-Schuler D, Hanssen-Bauer I and Førland EJ (2010a) Longterm climate trends of Finnmarksvidda, Northern-Norway. met.no. Rep. 06/2010 Climate. Norwegian Meteorological Institute, Oslo

Vikhamar-Schuler D, Førland EJ, Hanssen-Bauer I, Hygen HO, Nordli $\varnothing$ and Svyashchennikov P (2010b) Arctic communities and reindeer herders' vulnerability to changing climate: climate conditions in northern Eurasia since year 1900. met.no. Rep. 14/2010 Climate. Norwegian Meteorological Institute, Oslo

Vionnet $V$ and 7 others (2012) The detailed snowpack scheme Crocus and its implementation in SURFEX v7.2. Geosci. Model Dev., 5(3), 773-791 (doi: 10.5194/gmd-5773-2012)

Westermann S, Boike J, Langer M, Schuler TV and Etzelmüller B (2011) Modeling the impact of wintertime rain events on the thermal regime of permafrost. Cryosphere, 5(4), 945-959 (doi: 10.5194/tc-5-945-2011)

Yamaguchi S, Sato A and Lehning M (2004) Application of the numerical snowpack model (SNOWPACK) to the wet-snow region in Japan. Ann. Glaciol., 38, 266-272 (doi: 10.3189/ 172756404781815239) 